\title{
AUGUSTINE TOLTON'S STRUGGLE AS A BLACK CATHOLIC AGAINST DISCRIMINATION AS PORTRAYED IN FROM SLAVE TO PRIEST BY CAROLINE HEMESATH AND THEY CALLED HIM FATHER GUS BY ROY BAUER
}

\author{
Agnes Mira Damayanti \\ agnesmira14@gmail.com
}

\begin{abstract}
This thesis aims to analyze how Black Catholics overcome the discrimination against their life in American society during the nineteenth century and also to explore what are the impacts of Black Catholics struggle portrayed in the biographies entitled From Slave to Priest and They Called Him Father Gus.

The interdisciplinary approach applied in this thesis are including literature, sociology, and the concept of time and macro to micro by McDowell are used to enhance the analysis of Black Catholics' struggle against the discrimination that they got in American society during the nineteenth century.

The findings of the thesis show that Black Catholics did some actions to overcome the discrimination against their life in American society. The actions done by Black Catholics are the sign that they work hard struggling against the discrimination from whites, Catholic Church, and Black Protestants. Also, since this thesis highlights the impact of Black Catholics' struggle, it indicates that the struggle of Black Catholics, represented mostly by the struggle of Father Augustine Tolton, give the positive impacts such as maintaining the good relation among black and white Catholics, inspired Black Catholics to keep struggle for their faith and inspired the establishment of Black Catholics’ organizations.
\end{abstract}

Keywords: Black Catholics, Father Augustine Tolton, Struggle, Impacts

\section{Introduction}

The existence of Black Catholics in United States can be seen from the early history of Whites settlements and also since the beginning of slavery era. As a black people and also as Catholic believers, those Black Catholics faced the hard life. Besides of becoming slaves, they also had to face the discrimination not only by the Whites but also among Black itself, especially from Black Protestants. The discrimination from Black Protestants could exist due to the fact of the different practice and hierarchies among Christian believers. ${ }^{1}$

Raboteau in his essay entitled Black Catholics and Afro-American Religious History: Autobiographical Reflections mentioned that the apparent discrepancy between being Black and being Catholic is based upon the fact that very few AfricanAmerican have been Catholic. So, Black Catholics are the minority within the

\footnotetext{
${ }^{1}$ Bennett, J.B. Religion and the Rise of Jim Crow in New Orleans. Pricetown University Press, p.203.
} 
minority. For the Black Catholics, they found the discrimination, or they faced the religious prejudice from their fellow Blacks, the majority of whom were Protestants and racial discrimination from their fellow Catholics, the majority of whom were white (1986: 119).

In short, Black Catholics faced the hard life since they had to face three layers of discrimination as Catholic believers, first from Whites in general, from Black Protestants for more specific and also from the Catholic Church itself. The hard life that they face led them to fight against the discrimination and their position of being discriminated.

As has been noted that the existence of Black Catholics can be seen from the slavery era. There were also some priests that came from slave family also. They were James Augustine Healy (1830-1900), Patrick Francis Healy, S.J. (1834-1910), and Alexander Sherwood Healy (18361874). They were the Healy Brothers from mother Mary Eliza, a slave and her owner Michael Morris Healy, the Irish immigrant and landowner. The father sent those three children to the North, where they did not consider themselves as black. Even the Healy brothers became the priests from the beginning era, but many people did not recognize them as the first Black Catholic priest due the fact that they were not purely came from the Black family in which the father was Irish. ${ }^{2}$

There was a Black Catholic man from a slave family called Augustine Tolton (also some called him as Augustus Tolton) that successfully became the first Black Priest in the United States. The family had a background of becoming slaves. Both of his parents were slaves in Missouri and they were Catholic. During the Civil War, his family escaped from being slaves and went to the Mississippi River to Illinois. They settled in Quincy, where there was a community of escaped slaves and a black Catholic church, St. Joseph's. In the latter years, Augustus Tolton wanted to become a priest, so he tried to enter the American seminary. But because of the racial discrimination, there was no American seminary would accept a black candidate. So he decided to go to Rome and he entered the priest education there. In 1886, he went back to the United States and he was assigned to St. Joseph's in Quincy. After he went back to the United States and became a priest, he still

\footnotetext{
2 Craughwell, T.J. History of African-American Catholics. OSV Newsweekly. January 25, 2012. Web. June 20, 2015. <https://www.osv.com/OSVNewsweekly/By Issue/Article/>
} 
faced so many difficulties related to the racial discrimination. ${ }^{3}$

This study is going to investigate the struggle of Black Catholics as portrayed by the figure of Father Augustus Tolton. His figure as the first Black Priest in the United States can be the example of how Black Catholics tried to fight against the racial discrimination that they should face and how they should change their life for becoming better people as Catholic believers. Hemesath mentioned that Father Augustus Tolton was considered as a beacon of hope to Black Catholics in the nineteenth century who was trying to find a home in the American Church (2006: 9). Even previously it has been mentioned that Healy Brothers had precedingly become priests, but the background of their family cannot be considered as same as Father Augustus Tolton. Healy Brothers were mulatto since their father was a plantation owner. Here, Father Augustus Tolton came from both slave parents and he was purely Black Catholic. Due to that fact, many people considered Father Augustus Tolton as the first Black Catholic priest in the United States.

\footnotetext{
${ }^{3}$ Craughwell, T.J. History of African-American Catholics. OSV Newsweekly. January 25, 2012. Web. June 20, 2015. $<$ https://www.osv.com/OSVNewsweekly/ByIssue/ Article/>
}

The primary data of this research use two biographies of Father Augustus Tolton to explore how he struggles for achieving equality and also how they preserving his faith. The first biography that is used entitled From Slave to Priest- the Inspirational Story of Father Augustine Tolton by Caroline Hemesath, S.S.F. and the second biography is from Father Roy Bauer entitled They Called Him Father Gus. Even the emphasize in this research is the figure of Father Augustus Tolton as the representation of the Black Catholics struggle, in those two biographies, there are some Black Catholics that can be seen in the struggle. That is why the minor figures excluding Father Augustus Tolton can be used to find out about how their struggles as Black Catholics.

Furthermore, this research concerns on the struggle of Black Catholics since the topic of struggle can have the complex meaning to be investigated. If we try to explore the struggle, the study requires finding out the background for the struggle and also the impacts of the struggle itself. That is why taking the struggle of Black Catholics here can give the complex and in-depth analysis for the analysis of the study of Black Catholics that is portrayed in From Slave to Priest and They Called Him Father Gus. 
There are two objectives of the study, first is to elucidate how Black Catholics overcame the discrimination against them, their life in American society during the nineteenth century. Second objective is to explore what are the impacts of Black Catholics struggle as portrayed in From Slave to Priest and They Called Him Father Gus.

\section{Methodology}

This research belongs to qualitative research as it is mainly a literature study that relies mostly on library research. The researcher interprets the data in subjective manner using this mode of interpretation by using the micro and macro analysis and reconciliation of time perspective by McDowell to analyze and answer the proposed research question.

In accordance with the theoretical framework, the data used in this research are analyzed by using the approach of reconciliation of time and micro macro analysis by McDowell through the theory of racial discrimination to answer the proposed research questions. The main objects of this research are the biographies of Father Augustine Tolton entitled From Slave to Priest and They Called Him Father Gus is going to be treated as the main materials to find out the struggle of
Father Augustine Tolton and Black Catholics in general in facing the racial discrimination. Here are some steps in analyzing the data for the research:

Some sentences, quotes, lines, paragraphs, or parts from both of the biographies will be used as the data to be analyzed related to the proposed research questions. There are three main parts that are going to be investigated in this research.

The first investigation is related to the first research problem about how Black Catholics overcame the discrimination against them. In order to answer this research question, the analysis is going to be divided into two parts, first is going to explore about the reasons of the struggle itself. In order to explore the background of the struggle in which has the close relation with racial discrimination, the data that show about racial discrimination got by Black Catholics and also Father Augustine Tolton in specific including the statements, lines, and parts from both of the biographies are going to be used. Then, the theory of racial discrimination is used to analyze the racial discrimination. In this case, the secondary data about the racial discrimination that have the relation with Black Catholics are going to support the analysis. 
Furthermore, for analyzing how Black Catholics have to struggle, the researcher is going to find some actions done by Black Catholics and Father Augustine Tolton in specific from the biographies. The theory about the minority-group responses to prejudice and discrimination is going to be used to analyze the actions. Of course, the secondary data about acts shown by Black Catholics are going to be used to support the analysis.

The second research problem about what the impacts of the Black Catholics struggle are, the data about the impacts of Father Augustine Tolton's actions to struggle and also the other Black Catholics in both biographies are going to be investigated. Several sentences, lines, quotes, statements, or parts from the biographies that have the relation about it are going to be used for analyzing the data. Moreover, the supporting data about the impacts of the struggle from the secondary data are very needed in order to find out the significance of the struggle done by Father Tolton whether his actions inspired other Black Catholics for doing the same struggle for achieving the equality or not. In this case, the theory about the effect of prejudice and discrimination by Yinger is going to be used to analyze the data.

\section{Discussion}

Black Catholics in the United States had to face the hardship for their living during the nineteenth century like what's described in the previous chapter. The struggle of Black Catholics in facing the problems related to the racial discrimination is discussed further in this chapter, especially related to the condition that happened in the biographies of Father Augustine Tolton entitled From Slave to Priest and They Called Him Father Gus.

In both biographies; From Slave to Priest and They Called Him Father Gus, slavery existed due to the fact that the backgrounds of Father Augustine Tolton were from slave families. Both parents of Augustine Tolton were slaves. When they were still slaves, they did not get a good condition of living. Because the parents of Augustine Tolton were slaves, they had no control and power in their own life. Their masters were the one who had the control of the life and any kinds of things of the slave’s life. Bauer mentioned:

When the wealthy John Manning died, his widow married Stephen Burch. Manning's youngest daughter, Susan, married Stephen Elliot in 1849. Susan's step-father, of course, wanted to give a fine wedding present to Susan. He decided to give her some slaves. From his Negroes, he selected a half dozen of varying ages and abilities. 
...Among the slaves in Susan's dowry was the sixteen-year-old Martha Jane Chisley. Not included, however, were Martha Jane's parents and brother whom she loved dearly. A short time later, the newlyweds loaded their possessions in carts took their slaves and headed westward. The teenage slave girl, Martha Jane, would never see her parents again (1990: 1).

When Martha Jane, the mother of Augustine Tolton was still young, she had to be separated with her family and she would never be able to see them anymore. Due to the fact that Martha Jane was a slave to Manning's family, she had no control for determining how her life would be. Her master had the full authority for determining how the slave's life will be, including for the life of Martha Jane for separating her with her family to be given to the Susan Manning who married Stephen Elliot.

Slavery itself can be considered in the high level of discrimination. Seen from the levels of discrimination (Parillo, 1985: 80 ), slavery can be included in the fourth level out of five levels of discrimination, called as physical abuse. The Blacks who became the slaves had to work hard and do all of the things that the masters asked. The lives of the slaves were dedicated only for working for the masters.
Slavery can be categorized as institutional discrimination based on the division proposed by Fred L. Pincus. "Institutional discrimination refers to the policies of majority institutions, and the behavior of individuals who implement these policies and control these institutions, that are intended to have a differential and/or harmful effect on minority group. Institutional discrimination has the major goal to keep minority groups in a subordinate position within society” (Pincus \& Ehrlich, 1994: 83). The slavery itself is used by the Whites in order to keep the Blacks to have the subordinate position in the society. Slavery is the system used by Whites in general in order to control the Blacks so that they cannot have the better position in the society.

Besides getting the racial discrimination from the White people in general, Black Catholics also face the hardships as the result of the discrimination within the Catholic Church itself. Mostly, the racial discrimination faced by Black Catholics in both biographies entitled From Slave to Priest and They Called Him Father Gus is mostly about the discrimination faced by Father Augustine Tolton. The problems faced by Father Augustine Tolton here are mostly 
about the rejection of the seminaries in the United States to accept him as the candidate of priesthood.

In both biographies, it is stated that Augustine Tolton had the willingness of being a priest. In order to be a priest was not easy, Augustine had to enter the school for the priesthood candidate. The school for the priesthood candidate is called as Seminary. In the United States, there were some seminaries from some congregations. When Augustine was willing to become a priesthood candidate, there was no seminary in the United States which accepted Augustine as the priesthood candidate in their seminaries. Like Bauer mentioned:

In 1870, Augustine applied to be a postulant in the Franciscans, but his request was turned down. Then Father McGirr wrote the diocesan bishop about the devout, talented, and aspiring young man. The bishop advised father to "find a seminary which will accept a Negro candidate. ...the diocese will assume expenses.” The directive of Bishop Baltes was of no value, since Father McGirr had already written every seminary in the country and the responses all started with words like "we are not ready for a Negro student (1990: 7).

This condition can show how there is no seminary in the United States which is ready to accept the Black candidate for the priesthood. The condition happened due to the face that previously there is no Black who is interested to become a priesthood candidate. In addition, the position of Blacks in American society especially in Catholic Church was not good enough. They were still considered as inferior class toward the White parishes. So, when there was a Black young man wanted to enroll for the priesthood candidate, the seminaries in the United States were ready to accept it. The fact that there are no seminaries in the United States which accepted a Black Candidate for the priesthood can be happened due to some problems. The general cause here is commonly based on the reality that racial discrimination toward Blacks from Whites in this period of time was still strong.

Furthermore, the actions done by the seminaries in the United States in which they decided to reject Augustine Tolton as a priesthood candidate in their seminaries can be considered as exclusion action. Exclusion is in the third level of discrimination according to the division of levels of discrimination by Parillo. Exclusion can be like the separation from certain jobs, housing, education, or social organizations" (Parillo, 1985: 78). The actions done by seminaries in the United States which reject Augustine Tolton to be 
the priesthood candidate in their seminaries really shows how they try to have the separation with the Blacks even for the priesthood education.

The actions of rejecting Augustine Tolton in all of the seminaries in the United States can belong to institutional discrimination. Pincus mentioned that "this kind of discrimination refers to the policies from the majority institutions and also the behavior from the majority group which applied the policies in order to keep the minority group in the subordinate position in the society" (1994: 83). Here the case is really clear that there were no seminaries in the United States which accepted Agustine Tolton and in fact there was no black priest in the United States.

Besides of getting the discrimination from Whites and Catholic Church, Black Catholics also faced the discrimination from Black Protestants too. During this time in the nineteenth century, the condition of Catholics and Protestants was not in the good condition. Even Catholics and Protestants share the same Christianity principal; there are many kinds of differences among the Christians. Besides, since Protestants become the majority in the United States and Catholics become the minority among the Protestants, they do not have the stronger position compared to the Protestants in American society.

The development of Black Catholics parishes where Augustine Tolton belonged made the other non-Catholics became envious and they wanted to lure away the Catholicism of the Black Catholics. Hemesath mentioned:

The day school, to be exact opened on February 11, 1878, with twentyone pupils, and, in the course of the year, the number reached sixty. No wonder that the Protestants took sharp notice of the new enterprise designed to propagate the Catholic faith. On April 22, 1878, seven children of Saint Joseph's School were baptized. This occasioned a protest meeting on the part of Methodists and Baptists against the Catholics, and they adopted the unanimous resolution to send all their children to the public school. They employed every means possible to hinder the children from going to Catholic school (2006: 99).

The development of Catholic Church to maintain the parishes by having the Parish school made the Black Protestant community to be afraid that there would be many other people who will convert to Catholicism. Even when Augustine Tolton had been ordained as a priest, there was some inhibiting of factors that he had especially from the other community of Black Protestants. Hemesath mentioned: 
Father Tolton's work as a pastor was constantly impeded by the activities of churchmen representing nonCatholic denominations. They made their services so attractive to the blacks, the old and the young, that many of these were led away from the Catholic Church (2006: 173).

Here, the Black Protestants tried hard to do some ways to preserve the members of their community so their members would not convert to Catholicism and also they had the purpose to make the other Blacks to be attracted becoming the members of their denominations community.

The actions done by the Black Protestants to Black Catholics could be caused by competition. Like what proposed by Parillo, competition is one of the causes of discrimination and prejudice. In competition, people tend to be more hostile toward others when they feel their security is threatened. There are great amounts of evidence show that negative stereotyping, prejudice, and discrimination increase strongly when the condition of a competition for a limited number of jobs increases (Parillo, 1985: 73-74). Here, the Black Protestants felt that their security in which the good condition of their parishes was threatened with the existence of Black Catholics. Moreover, the development of Black Catholics made them to be afraid that the numbers of Black Protestants decrease. That was why they tried hard to do some ways in order to maintain the numbers of their members and also if it was possible to increase the numbers of their members by luring the numbers of Black Catholics to lure away from their faith.

Despite of getting the racial discrimination from White people in general, from Catholic Church and also from the Black Protestants that make the Black Catholics face the hardships, in order to get the better living they have to struggle. Of course there are some actions done by Black Catholics in order to struggle as the reaction of the racial discrimination that they face.

Like stated earlier, Whites discriminated the Blacks in common. Here, the Black Catholics also received the discrimination from Whites in general also. As the actions against White discrimination, there were some actions done by the Black Catholics. For the first case, slavery, there were some actions done by Black Catholics in order to struggle. Here, the actions for struggling from slavery were done by the family of Augustine Tolton. Bauer mentioned:

Fully aware of the dangers involved with escape, Martha Jane decided to try to escape with her children. Runaways were often caught 
because slave owners had organized groups, with orders to hunt, shoot and even kill, any Negro not in chains after nightfall. ...Whatever the circumstances, Martha Jane was able to get her three children out of the slave quarters and head for Quincy, Illinois (1990: 4).

Escaping from slavery was considered as the right choice to choose since the condition in the plantation was not good for the directness of Mrs. Tolton and his children living. During the period of Civil War era, there were many numbers of slaves who escaped from their masters. The escaped slaves called as fugitive slaves. "Fugitive slaves" or "runaways slaves" refers to the slaves who left their master and traveled without authorization. They generally tried to reach states or territories where slavery was banned. ${ }^{4}$

In addition, after the fugitive slaves escaped from their masters, they had to get the job for their own living. On reaching Union lines, runaways might find employment-as laborers, cooks, teamsters, washerwomen, or nurses. ${ }^{5}$ In

\footnotetext{
${ }^{4}$ Renford, Reese (2011). "Canada; The Promised Land for Slaves". Western Journal of Black Studies 35 (3): 208-217

${ }^{5}$ Rasmussen, William. How Did Slaves Escape? Virginia Historical Society’s Blog. Oct 10, 2010. Web. 19 March 2016.

$<$ https:/vahistorical.wordpress.com/2010/10/20/ho w-did-slaves-escape/>
}

this case, the Toltons who could be considered as fugitive slaves, after their escaping process, they looked for a job also for struggling in their living. Specifically, the condition also became the same for the Toltons since after they arrived in Quincy; they had to earn money by working in the cigarette factory.

Overall, Black Catholics here were actively showing their actions against the racial discrimination from Whites domination. They actively wanted to do something to break the discrimination from Whites in general. As the main root problem of the discrimination was the slavery. The Black Catholics in this case represented by Tolton did the defiance actions in order to break the slavery that they got. Defiance is one of the forms used as the minority-group responses to prejudice and discrimination. Parillo mentioned that if "a minority group is sufficiently cohesive and conscious of its growing economic or political power; its members may act openly to challenge and eliminate discrimination practices. Sometimes the defiance appears as spontaneous, although it is usually the outgrowth of long-standing conditions" (1985: 88). In this case, the Black Catholics represented by the Tolton tried 
to escape from the slavery as the action that challenge and eliminate the slavery.

Despite the fact that Black Catholics also faced the discrimination not only from Whites in general, from the Catholic Church itself they had to face the discrimination. The hardship faced by Black Catholics as the results of the discrimination from Catholic Church led them to do some actions for struggling. In both biographies, From Slave to Priest and They Called Him Father Gus, the struggle itself can be seen clearly from the struggle of Augustine Tolton on how he could achieve his dream to be a priest.

In general, there were some actions done by Augustine Tolton when he showed his willingness to be a priest. Even in fact, there was no seminary in the United States which accepted him as the priesthood candidate, some helps from the Irish and German priests really made him to be ready for preparing himself for the priesthood candidate. Bauer mentioned:

When no seminary or religious order in the country would accept him because of his race, the priests in Quincy decided to tutor Gus locally. The city was blessed with welleducated priests, both diocesan and Franciscans (1990: 7).

Generally, there were some helps from both diocesan and Franciscan priests for tutoring and preparing Augustine Tolton for the priesthood education. The tutoring from some priests can be seen like mentioned by Hemesath:

The new pastor of Saint Boniface parish made immediate and earnest efforts to fulfill the last request of his predecessor- to help Augustine Tolton on his way to the priesthood. ...Soon Father Ostrop was planning a series for the young man (2006: 63).

Besides for helping Augustine Tolton with some tutoring, Father McGirr who had accepted him in the parish school when he was rejected in some schools also helped him financially. Hemesath mentioned:

Meanwhile, Father McGirr redoubled his interest in the candidate for the priesthood. One of the first ways in which he helped Augustine financially was by employing him as part-time custodian of Saint Peter's parish. ..For the six winters, Augustine had charge of the church, school, and rectory heating plants. Besides that he did as much as the parish chores as his time away from work allowed (2006: 61).

Moreover, the help from the diocesan or Franciscan priests were not only stopped on the local tutoring only but the priests also helped him for getting the formal education for preparing him in priesthood. Those are the examples of the 
helps given by the diocesan or Franciscans priests to help Augustine Tolton in preparing for the priesthood education due to the fact that there was no seminary in the United States that accepted him. Mostly, those priests were Irish or Germany. If seen from the history, Irish for particular had the good relations with Blacks. Irish can be considered as the white minority among other Whites in American society.

The good relations among Irish and Blacks in the United States can be seen clearly from their first existence in this country. Both Irish and Blacks shared the similar condition for their living in the United States. Both Irish and Africans were taken across the Atlantic - Africans as slaves and Irish as indentured servants, not quite slaves but with similar conditions and both treated as less than human. ${ }^{6}$ The Irish who immigrated to America in the 18th and 19th centuries were fleeing caste oppression and a system of landlordism that made the material conditions of the Irish peasant comparable to those of an American slave. They commonly found

\footnotetext{
${ }^{6}$ Mulraney, Frances. Black Irish Identities: The complex relationship between Irish and African Americans. Irish Central. 24 Sept. 2015. Web. 20 March. 2016.

$<$ http://www.irishcentral.com/roots/genealogy/Blac k-Irish-Identities-The-complex-relationshipbetween-Irish-and-African-Americans.html>
}

themselves thrown together with free Negroes. Blacks and the Irish fought each other and the police, socialized and occasionally intermarried, and developed a common culture of the lowly. They also both suffered the scorn of those better situated. $^{7}$

Overall, his strong hard work, dedication for struggling in reaching his dream for the priesthood could give the good result for his priesthood candidate. Finally, he could be accepted in Propaganda College in Rome even he could reach it with the help of other priests also despite of his hard work. The hard work and the dedication for struggling done by Agustine Tolton for the priesthood were not easy. Sometimes, he also felt so frustrated and loss of his selfconfidence when there was no seminary which was willing to accept him. Hemesath mentioned:

He imagined himself at the altar offering Mass and speaking before the congregation about the "goodness of the Lord". He reveled in this ecstasy for a while, and then his mind suddenly plunged back into a world of reality. He was black-an outcast- a runaway slave - a tobacco

\footnotetext{
${ }^{7}$ Ignatiev, Noel. The Divide Between Blacks and the Irish. The Root. 17 March. 2010. Web. 20 March. 2016.

<http://www.theroot.com/articles/culture/2010/03/s t_patricks_day_the_divide_between_blacks_and_th e_irish.html>
} 
factory hand - the breadwinner for a poverty-stricken family (2006: 55).

This kind of mind is the negative selfimage as the consequence from minority group toward discrimination and prejudice. A person's self-image includes race, religion, and nationality, thus individuals may feel ashamed and inferior if they are aware that any of these attributes are held in low esteem within the society. As the effects, the minority group members begin to perceive themselves as negatively as the dominant group originally perceived them (Parillo, 1985: 91). In this case, since Augustine Tolton got the rejection in all seminaries in the United States due to his race caused him to have the negative selfimage toward himself.

Like what has been discussed in the previous part that Black Catholics in both biographies entitled From Slave to Priest and They Called Him Father Gus did not only face the discrimination from the Whites in general and also the Catholic Church. From the fellow blacks, especially from the Black Protestants, they also had to face the discrimination. The problems that led to the discrimination from the Black Protestants to the Black Catholics were because of the worry of them for the development of Black Catholics. There were some protest actions done by Black
Protestants to Black Catholics including for doing some ways for luring the Catholicism.

Facing this kind of condition did not make Father Augustine Tolton as the priest in the Black parish when he was still in St. Joseph parish in Quincy tried to do some ways for protesting back the actions done by Black Protestants. Hemesath mentioned:

Father Tolton, who understood the zeal as well as the tenets of nonCatholics, resolved to maintain amicable and respectful relations with all members of other religious persuasions. He respected their convictions and carefully refrained from downgrading their forms of religious worships (2006: 181).

What was done by Father Augustine Tolton here can be considered as the wise way for maintaining the condition among fellow Black Christians in his society. As the Catholic leader in Quincy, it was very important for him to maintain the good relation with the other religious leader, including the Protestant denomination in the place close to his parish in Quincy. Even when the Protestant denominations did some protest actions for the development of Black Catholic parishes, what was done by Father Augustine Tolton could be categorized as the safest way. 
It is avoidance toward the further conflict among fellow Black Christian. The actions done by Father Augustine Tolton can be considered as avoidance as the minority-group responses to discrimination done by Black Protestants Avoidance can be said as a way for dealing with discrimination, a way to leave one's problems behind (Parillo, 1985: 86). Keeping and maintaining the respects done by Father Augustine Tolton is the avoidance of the discrimination done by Black Protestants so that the problem will not go further to be more complicated.

Furthermore, the actions done by Black Catholics as the way to struggle against the racial discrimination gives significant impacts for the existence of Black Catholics in the United States. Here the impacts of the struggles can be clearly seen from the actions done by Father Augustine Tolton as the representation of Black Catholics who struggle for getting the right for being a priest.

\section{The Good Relation among White and Black Catholics}

The ordination of Father Augustine Tolton gave the significant impact for the condition of Black Catholics, especially for the Black Catholics in his parish, in Quincy. His struggle to reach his dream of being a priest gave a good impact since he could become a priest. When he became a priest in St. Joseph Church in Quincy, there were some changes for the condition of Black Catholics. Hemesath mentioned:

Further evidence of amicable race relations is found in the existence and growth of Saint Joseph's Altar Society. The organization of fortyeight members had been founded before the coming of Father Tolton. Eventually the membership increased and consisted of eighty black and white women. During its regular meeting the society worked effectively toward the material up keep of the parish. Through group interest and cooperation substantial sums were raised to help maintain the church and school (2006: 171).

This condition can show that there were an increasing number of the members of Saint Joseph's Altar Society. Altar Society is a group of people who serve for preparing the altar for the mass. They have the duty for cleaning and preparing any kinds of requirements for the mass. The members here majority are women. ${ }^{8}$ Moreover, the existence of white women in this Black Church could become the indication that the whites and the blacks were able to work together for serving the mass or

\footnotetext{
${ }^{8}$ Langlois, Ed. Parish Altar Societies Provide Quiet, Prayerful Service to God. Catholic Sentinel. 1 Jan 1999. Web. 19 May 2016.

$<$ www.catholicsentinel.org/main.asp?SectionID=2 \&SubSectionID=35\&ArticleID=3832>
} 
working together for the growth of the parish itself.

In general, the struggles of Father Augustine Tolton after he was ordained as a priest give the good impact or positive impact toward the condition of Black Catholics community. The good impact of the Black Catholics community in St. Joseph's Church or the parish where Father Tolton was assigned to lead had the good relations among whites and black Catholics as the result of actions done by Father Tolton to handle his parish. The blacks Catholics can gather with the whites and it means that they can accept the whites in their black society also. These kinds of condition reflect the positive impact from the struggle of Father Tolton. If related to the impact of prejudice and racial discrimination according to Simpson and Yinger, one of the impacts is selfconfidence and group identification has increased among Negroes. There have been some forces to encourage them to take pride in their racial identity (1965: 149). The situation is closely related since Father Augustine Tolton as the black priest in the black Church had the confidence to accept the white Catholics in his parish and their attendance in his black Church encouraged him to lead the black Church.

\section{Inspiring Black Catholics to Keep Struggling for Their Faith}

The death of Father Augustine Tolton itself also gave the big impact to the condition of the Church service. When the church services were reduced not like when Father Augustine Tolton was still alive, the Black Catholics in St. Monica's church of course got the difficulty for attending the mass and doing the religious practice. Even the condition was difficult for them after the death of Father Augustine Tolton, the spirit of Father Tolton still alive with them. The struggle of Father Augustine Tolton when he was still alive and ministered this parish made the Black Catholics in this parish keep the spirit was with them. Like what mentioned by Hemesath:

Two years after the death of Father Tolton, members of Saint Monica's parish called a meeting to discuss the state of affairs and to formulate plans for action. First, they decided upon delegation to speak for them to the archbishop...In view of these conjectures members of the meeting suggested that they try to get a priest from the Josephite Society in Baltimore (2006: 226).

The initiation of Black Catholics in Saint Monica's Church to have a meeting discussing about the further condition of their parish could show how they had the willingness for keeping their own church. 
They wanted to preserve the existence of their own community and their own Black Catholics' church and conducting the meeting for the discussion here is one of the real acts concerning about their church.

\section{The Establishment of Black Catholics Organizations}

The spirit of Father Augustine Tolton's struggle not merely inspired the Black Catholics parish in Saint Monica’s church. There are some organizations established as the result for the inspiration of Father Augustine Tolton. Hemesath mentioned:

There are other reminders that 'the spirit' of Father Tolton is marching.” Organizations dating from his day are living monuments to his leadership and influence. One of these is Ladies Catholic Benevolent Association (L.B.C.A), directed today [1973] by Mrs. Mamie Saunders. ... Two years after the death of Father Tolton, the Women's Catholic Order of Foresters (W.C.O.F) was established with Mrs. Cora Spriggs as leader. This fraternal society is still active today, and blazoned on its banner is: Augustine Tolton No. 391 (2006: 233).

The establishment of some organizations in Saint Monica's parish after the death of Father Augustine Tolton such as Ladies Catholic Benevolent Association and also Women's Catholic
Order of Foresters is the sign that the Black Catholics in this parish again make the initiation for making their community to be stronger. Like mentioned in the quotation that they still have the spirit of Father Augustine Tolton and it means that they are inspired by the actions struggle from Father Tolton for their parish. The actions for struggling are the starting point to acquire group identification.

\section{The Raising Conflict from Black Protestants}

Like mentioned in the previous discussion, there was a problem with Black Protestants while Father Tolton became the priest in Black parish. Hemesath mentioned:

The wide publicity and munificent praise which heralded the coming of Father Tolton added fuel to the wrath of certain Protestant church leaders. They redoubled their efforts not only to save their own church members from "Romanism", but they also made many efforts to lure Catholics from the fold (2006: 182).

Father Tolton actions as a priest in his Black parish can give the good impact for the people of his parish but it can also make the other people like here Black Protestants not so happy. It made certain Protestant church leaders became worried for the development of their own church. 
Here, they were afraid that they would find the decreased number of their church members. Somehow, luring Catholicism and made the sermons became more attractive were done by them to attract more Catholics people to their church denomination.

\section{The Jealousy from White Priest}

Like what mentioned in the previous discussion that Father Weiss was jealous to Father Tolton due to the fact that many of his parish were attracted to attend Father Tolton mass. Bauer mentioned:

But the worst hurt came when a new pastor was assigned to St. Boniface Church, who was also appointed as the dean or leader of the Quincy area Catholic clergy. Father Michael Weiss arrived in Quincy in November of 1887. ...He was unhappy about his parish maintaining the church building for the Negro parish, and he was especially unhappy because many of his parishioners frequently attended services at St. Joseph Church (1990: 25).

The condition shown by Bauer above clearly show how a white priest was not happy with the existence of Father Tolton in the parish close to his own parish. Even they share the same job as a priest, the white priest here did not see him as the same priest with him. The fact that many of his parishioners liked to attend the service at St. Joseph Church where Father Tolton was ministered made Father Weiss was unhappy. Here he showed the jealousy and feeling of unhappy. Those kind of feelings can be the sign that he still looked down at Father Tolton as a black priest and he did not want to be competed with the black priest.

\section{Conclusion}

From analyzing the biographies entitled From Slave to Priest and They Called Him Father Gus, the researcher concludes that the actions taken the Black Catholics take were varied based on who they were struggling against from. The researcher divides the actions for struggling in three context, namely from Whites dominancy, from Catholic Church, and from the Black Protestants. From the Whites dominancy, actions like escaping from slavery then starting a new life by getting a new job and enrolling the children to school were the ways done by Black Catholics. Next, from the Catholic Church, the actions like being active in the local tutoring for the priesthood education were also done by Father Tolton as a Black Catholic. Furthermore, the actions to overcome the discrimination against Black Catholics can be seen from the Black Protestants context also. The actions like 
maintaining amicable and respectful relations with all members of other religious groups could be considered as the democratic way.

Hence, the struggles done by Black Catholics gave the big impacts not only for the condition of Black Catholics but Catholics in general. Some impacts of the struggle are, first, the existence of Father Tolton as a priest gave the positive impacts for his Black Catholics community since there were many white people who had the willingness to attend his mass. The existence of whites in his parish bridges a good relation among blacks and whites Catholics. Besides, after the death of Father Tolton, the black parish of his church was inspired to keep struggle for their faith. Third, after the death of Father Tolton, there were some establishments of Black Catholics' organizations like Ladies Catholic Benevolent Association and also Women's Catholic Order of Foresters. In addition, there are also some negative impacts as the result of Father Tolton's struggle. With his role as a priest in Black parish, here are some problem appear as the impact of the struggle like the raising conflict from Black Protestants. Then, the other negative impact was about the jealousy from white priest to Father Tolton.

\section{References}

Bauer, Roy. 1990. They Called Him Father Gus: The Life and Times of Augustine Tolton, First Black Priest in the U.S.A.

Cresswell, J.W. 2009. Research Design Qualitative, Quantitative, and Mixed Methods Apporaches. California: Sage Publications Inc. Print

Davis, Cyprian. 1990. The History of Black Catholics in the United States. New York: Crossroad. Print.

Hemesath, Caroline. 2006. From Slave To Priest, The Inspirational Story of Father Augustine Tolton. San Fransisco: Ignatius Press. Print.

McDowell, Tremaine. 1948. American Studies. Minnesota: The University of Minnesota Press. Print.

Merideth, Robert. 1968. American Studies Essay on Theory and Method. Miami: Charles E. Merrill Publishing. Print.

Parillo, V.N. 1985. Strangers to These Shores: Race and Ethnic Relations in the United States. New York: Macmillan Publishing Company. Print.

Pincus, F.L. \& Ehrlich, H.J. 1994. Race and Ethnic Conflict. Colorado: Westview Press. Print.

Simpson, G.A. \& Yinger, J.M. 1965. Racial and Cultural Minorities ( $3^{\text {rd }}$ ed.). New York: Harper \&Row Publishers. Print. Raboteau, A.J. "Black Catholics and Afro-American Religious History: Autobiographies Reflection.” U.S. 
RUBIKON Volume 4 / Number 2

September 2017

Catholic Historian 5.1. (1986): 119-127. JSTOR. Web. 24 Oct. 2015. 